\title{
Effects of Unmanaged Sports-Related Conflicts among Colleges of Education Students in Ghana.
}

\author{
Richmond Stephen Sorkpor, Emily Araba Forson, Bismark Tsorhe \\ Tutor, OLA College of Education- Cape Coast \\ Tutor, OLA College of Education-Cape Coast \\ Tutor, St Teresa's College of Education- Hohoe
}

\begin{abstract}
The purpose of the study was to unravel and analyze effects of sports-related-conflicts in the CentralWestern Zone of Colleges of Education in Ghana. Quantitative descriptive survey was used to unravel the effects of sports-related-conflicts among students in the Colleges of Education in the Central Western zone. A questionnaire was administered to 369 respondents. Data collected was analyzed using descriptive statistics. It was revealed that the effects of sports-related-conflicts assumed different forms including; creation of state of chaos, destruction of property, retaliation, sowing seeds of bitterness, rough play action, suspicion, unnecessary tensions, blackmailing among others. It was recommended that conflicts in sports at the Colleges of Education in Ghana should be properly managed by the organizers of the sporting activities
\end{abstract}

\section{Key Words; Rough playaction, Blackmailing, Seeds of bitterness}

\section{Introduction}

Conflict is an unavoidable aspect of modern life. Once people from different communal, racial, religious, political and economical settings are assembled together, the opportunity for conflict increases. This also means conflict in general is pervasive and may happen in any organization, institutions inclusive. It is therefore, not surprising those gatherings such as Central-Western zone sports competitions may be besieged with its fair share of conflict.

Kreitner and Kinicki (2001) were of the view that conflict is a situation in which an effort is made by someone to offset the efforts of another by some form of blocking that will result in frustrating the other in attaining goals and interests. They further stated that the parties to a conflict may be individuals or groups because institutions bring together people with diverse backgrounds. They stress that conflicts and disputes are, therefore, part of life of any human institution. Therefore, there is no society or interpersonal relationship which does not experience conflict at some time or another as part of social life.

Conflict is a serious disagreement, arising out of differences of opinion, wishes, needs, values, and interests between and among individuals or groups (Hornby, 1995). It is also a struggle between and among individuals and groups over values and claims to scarce resources, status symbols, and power bases. The objective of individuals or groups engaged in conflict is to neutralize, injure, or eliminate their rivals so that they can enjoy the scarce resources and the status symbols (Coser, 1965).

A potential for conflict exists whenever and wherever people have contact (Barker, Kathy, Kittie, \& Robert, 2001). As people are organized into groups to seek a common goal, the probability of conflict greatly increases since individuals may dislike certain people with whom they come into frequent contact. There are disagreements with family members, friends, and co-workers and even people we meet for the first time. These conflict situations appear with frequency in daily, public, and private life and may be either on a small or large scale.

The existence of conflict may be triggered by ethnic, racial, religious, economic differences, or may arise from differences in values, beliefs and attitudes regarding issues. A conflict may become violent, and in extreme cases, leading to destruction and bloodshed. This does not necessarily mean that all conflicts are 
bound to lead to violence; the situation becomes so when the process turns to overt hostility that involves destructive behaviour (Robinson, 1972).

Conflict in organizations can range from trivial to tragic and may occur within the individual, between people, and between groups. It is closely related to change and interpersonal transactions .As people come together to satisfy a wide range of emotional needs, social relations in general are swamped with conflict. As people interact, they deal with differences as well as similarities; with strong dislikes as well as attractions (Kreitner, 1998). In social relations, Sigmud Freud's parallel of humans and porcupines is suitable. Freud intimates that like porcupines, people prick and injure one another if they get close, and feel cold if they get too far apart.

One school of thought feels the term conflict has a strong negative connotation, evoking words such as rivalry, anger and violence. Another school of thought, however, feels conflict does not have to be negative experience. It can serve as an important positive force in the achievement of organizational goals. Conflict, however, is an everyday certainty with both benefits and costs. In recent times, it was inferred that organizational conflict of any type was detrimental and should be eradicated. Now, however, the potential positive outcomes of conflicts such as providing feedback, indicating the need for change, making supervisors aware of problems and increasing motivation are being recognized. Wright and Noe (1996) intimated that because conflict is usually uncomfortable, people tend to think of it as bad. They were, however, of the view that if people handled a conflict with mutual respect and trust and achieved an outcome that was favorable to the organization, conflict could be a positive force.

\section{Statement of the Problem}

According to Mensah. K. (2001), there was four different Sports related conflicts recorded in Africa in four weeks that same year with damaging effects. On April 11, 43 people were killed at a stadium in Johannesburg, South Africa. Eight fans perished in another conflict in Lubumbashi, DR Congo, on April 29. On May 7, fighting broke out among fans at a soccer match in Ivory Coast, killing one person and injuring 39. And on May 9, 127 fans perished at Ohene Djan Sports stadium during a soccer match between Accra Hearts of Oak and Kumasi Asante Kotoko. Various institutions of higher learning also witness various forms of sports related conflicts especially during inter hall competitions.

Conflict situations are created by varied factors and so the types and nature of conflicts differ from one institution to the other. Conflicts come with their attending effects which at times leave behind damaging scars in the memory of generations even unborn. In Central-Western Zone of Colleges of Education, it was obvious that various types of conflicts were witnessed in the past six years during zonal competitions and nobody could accurately tell what actually caused them and how to curtail them. It was, therefore, extremely difficult for the administration and organizers to strategize measures to deal with conflicts which disrupted various sports competitions in the zone. The phenomenon was also destroying the purpose of sports in the zone thus creating enmity among various members. There was, therefore, the need for an empirical study of the effects of the conflicts in the zone to facilitate formulation of practical resolutions to cure the effects. This study was in response to the aforementioned need.

\section{Purpose of the Study}

The purpose of the study was to unravel and analyze effects of unmanaged sports-related-conflicts in the Central-Western Zone of Colleges of Education in Ghana.

\section{Research Question}

1. What are the effects of unmanaged sports-related conflicts in the Central-Western Zone Colleges of Education in Ghana?

\section{Methodology}

Descriptive survey design was used. The target population for the study was four thousand, six hundred and eighty one $(4,681)$ student trainees and tutors in the six colleges of education in the central-western zone in 
the 2009/2010 academic year. The six colleges being referred to were OLA, Holy Child, Fosu, Komenda, Wiawso and Enchi.

A sample size of three hundred and sixty nine (369) respondents was used for the study. The stratified sampling and simple random sampling methods were used to select the sample. The six colleges were put into six strata with each college forming one stratum. Since the population in the colleges differed, the proportional sampling in selecting the number of respondents from each college was used.

The instrument developed for the study was a questionnaire. Respondents were requested to respond to each item on a four-point Likert's scale.

\section{Results/Discussions}

The study sought to find out the effects of unmanaged sports related conflicts in the Colleges of Education in Ghana and the result is presented on Table 1.

Table 1: Effects of Unmanaged Sports Related Conflicts in the Colleges of Education

\begin{tabular}{|lcc|}
\hline Effects of unmanaged conflict & Frequency & Percentage (\%) \\
\hline Chaos & 89 & 24.1 \\
Destruction of property & 52 & 14.1 \\
Seed of bitterness & 45 & 12.1 \\
Retaliation & 43 & 11.7 \\
Unnecessary tension & 39 & 10.6 \\
Suspicion & 37 & 10.0 \\
Blackmailing & 35 & 9.5 \\
Rough play or action & 29 & 7.9 \\
\hline Total & $\mathbf{3 6 9}$ & $\mathbf{1 0 0}$ \\
\hline
\end{tabular}

\section{Source: Field Data}

From Table 1,out of the 369 respondents, 89 (24.1\%) were of the view that unmanaged conflict during sports competition in the Colleges of Education in Central-Western zone resulted in chaos, 52 (14.1\%) said it resulted in injuries and destruction of property, $45(12.1 \%)$ said it resulted in seed of bitterness, 43 $(11.7 \%)$ said it resulted in looking for means of retaliation, $39(10.6 \%)$ said it resulted in unnecessary tension, $37(10.0 \%)$ said it resulted in suspicion, $35(9.5 \%)$ said it resulted in blackmailing, whereas 29 (7.9\%) said it resulted in rough play or actions. The effects of conflict on the individual can be very detrimental to the success of any organization. This can be likened to Wright and Noe's (1996) explanation of effects of conflict leading to the reduction of morale and coordination. These various effects of unmanaged conflict as indicated by respondents are mirrored in the Colleges of Education in CentralWestern zone to the extent that some students are not on talking terms with their counterparts in other colleges in the zone. There are other instances where the tension created is so high that students from a particular college attending zonal sports festival would be unwilling to share the same floor with another. A summary of the answers to research question are chaos, injuries and destruction of property, seed of bitterness, looking for means of retaliation, unnecessary tension, suspicion, blackmailing and rough play or action.

\section{Conclusions}

This study sought to assess the effects of unmanaged sports-related-conflicts in the life of students in the Colleges of Education in Ghana. From the findings, it can be concluded that the effects leave memorable scars in the life of students resulting in retaliation, sowing seeds of bitterness, creation of state of chaos, suspicion, unnecessary tension, blackmailing and destruction of property among others.

\section{Recommendations}


1. Conflicts in sports at the Colleges of Education in Ghana should be properly managed by the organizers of the sporting activities.

2. Students in the Colleges of Education should be taken through the dangers and effects associated with conflicts in sports.

\section{References}

[1] Agyedu, G. O., Donkor, F., \& Obeng, S. (1999). Research methods. Kumasi: University of Education, Winneba.

[2] Anderson, G. (1990). Fundamental of education. London: The Palmer Press.

[3] Barker, J., Tjosvold, D., \& Andrews, R. I. (1988). Conflict approaches of effective project managers: A field study in a matrix organization. Journal of Management Studies, 2, 167 176.

[4] Barker, L. L., Kathy, J. W., Kittie, W., \& Robert, J. K. (2001). Groups in Process: An introduction to small group communication. New York: Prentice Hall.

[5] Bateman, S. T., \& Scott, S. A. (1999). Management building competitive advantage. New York: Irwin McGraw Hill.

[6] Collins, E. C. (1992). Qualitative research as art: Towards a holistic process. Theory into Practice, XXX1(2), 181-186.

[7] Coser, L. A. (1965). Conflict: Social aspects. International Encyclopedia of the Social Sciences, 3, 232-245.

[8] Creswell, J. W. (2003). Research design: Qualitative, quantitative, and mixed methods approaches. $\left(2^{\text {nd }}\right.$ ed.) London: SAGE Publications Inc. Holbrook Press.

[9] Fink, C. (1995). How to sample in surveys. California: Sage Publications Inc.

[10] Fisher, S., Ludin, J., Williams, S., Abdi, D., \& Smith, R. (2000). Working with conflict skills and strategies for action. London: Zed Books Ltd.

[11] Gardner, J. W. (1990). On leadership. New York; The Free Press

[12] Himes, J. S. (1980). Conflict and Conflict Management. Athens: University of Georgia Press.

[13] Hornsby, A. S. (1995). Oxford Advanced Learner's Dictionary of Current English (5th Edition) London: Oxford University Press.

[14] Huezynski, A., \& Buchanan, D. (2001). Organizational behaviour: An introductory text $\left(4^{\text {th }}\right.$ ed). London: Prentice Hall.

[15] Kerlinger, F. N. (1973). Foundations of behavioural research. New York: Rinehart\& Winston.

[16] Koul, L. (2002). Methodology of educational research. New Delhi: Vikas Publishing House PVT Limited.

[17] Kreitner, R. (1998). Management. U.S.A.: Houghton Miflin Company.

[18] Kuutson, T. J., \& Kowitz, A. C. (1997). Efforts of information type and level of orientation on consensus achievement in substantive and affective small group conflict. CentralStates Speech Journal, (28), $54-63$. .

[19] Mack, R. W. (2000). The components of social conflict readings in community organization practice. New Jersey: Prentice Hall, Inc.

[20] Mensa-Bonsu, B., \& Effah, P. (2003). Conflict management and resolution skills for managers of tertiary education institutions. Accra: National Council for Tertiary Education.

[21] Menash, K. (2001). When the beautiful game become ugly. http://www.goal.com/en$\mathrm{gh} / \mathrm{news} / 4375 / \mathrm{comment} / 2013 / 05 / 09 / 3965585 /$ may-9-2001

[22] Owens, R. G. (2004). Organizational behaviour. New York: Pearson Education Inc.

[23] Rahim, M. A. (1983). A measure of styles of handling interpersonal conflict. Academy of Management Journal, 5, 368 - 376. .

[24] Robbins, S. P. (1997). Conflict management and conflict resolution are not synonymous terms. California Management Review, 21 (2), 43 - 67.

[25] Robinson, J. W. (1972). The management of conflict. Journal of the Development Society, 3 (2), $100-105$.

[26] Thomas, K. (1976). Conflict and conflict management. Chicago: Rand McNally and Company. 
[27] Wall, J.A., \& Callister, R.R. (1995). Conflict and its Management. Journal of Management, 3, 517523. 